\title{
Central Muscarinic Acetylcholine Receptor Availability in Patients Treated with Clozapine
}

\author{
Thomas J Raedler', ${ }^{1,2}$ Michael B Knable ${ }^{1,3}$, Douglas W Jones', Richard A Urbina', Michael F Egan' and Daniel \\ R Weinberger*, I \\ 'National Institute of Mental Health, Intramural Research Program, Clinical Brain Disorders Branch, Bethesda, MD, USA
}

\begin{abstract}
Clozapine is the prototypical atypical antipsychotic. In vitro, clozapine antagonizes a broad range of receptors, including dopamine, serotonin and muscarinic acetylcholine receptors. In vivo, receptor occupancy studies have shown moderate dopamine $D_{2}$ receptor blockade as well as high serotonin $5 \mathrm{HT}_{2}$ receptor blockade for clozapine. Using [-123]IQNB SPECT, we explored the influence of clozapine on muscarinic receptors in vivo. Eight schizophrenia patients underwent a total of 12 [I- I23]IQNB SPECT scans after treatment with low to moderate doses of clozapine (mean $210 \mathrm{mg} /$ day, range $50-450 \mathrm{mg} /$ day). Muscarinic receptor availability was determined for basal ganglia, cortex, thalamus, and pons. A group of 12 age- and sex-matched unmedicated schizophrenia patients was used for comparison. Compared to unmedicated patients, [1-123]IQNB binding was lower in all regions in subjects treated with clozapine and decreased with increasing dose. In patients treated with a daily clozapine dose of at least $200 \mathrm{mg}$ (mean $275 \pm 88 \mathrm{mg} /$ day), these differences were highly significant $(p<0.003)$ with mean reductions of muscarinic receptor availability of $45 \%$ for basal ganglia, $58 \%$ for cortex, $66 \%$ for pons, and $79 \%$ for thalamus. These preliminary data indicate that reduction of muscarinic receptor availability by clozapine can be measured in vivo and that moderate daily doses are associated with moderate to high reductions of muscarinic receptor availability. These results may explain, at least in part, the lack of extrapyramidal side effects as well as some side effects seen with clozapine.

Neuropsychopharmacology (2003) 28, I53 I-1537, advance online publication, I I June 2003; doi: 10. 1038/sj.npp. I 3002 10
\end{abstract}

Keywords: muscarinic receptor; clozapine; IQNB; SPECT; schizophrenia; antipsychotic

\section{INTRODUCTION}

Clozapine is a tetracyclic dibenzodiazepine that was synthesized in 1958 and has been available for clinical use since the 1970s. After being withdrawn for its potential to cause agranulocytosis, clozapine was reintroduced in the United States in 1990 with the requirement of weekly leukocyte counts. Due to its lack of extrapyramidal side effects and superior clinical efficacy, particularly for treatment of refractory schizophrenic patients (Kane et al, 1988; Rosenheck et al, 1997), clozapine is regarded as the prototypical atypical antipsychotic.

*Correspondence: Dr DR Weinberger, Clinical Brain Disorders Branch, $\mathrm{NIMH}$, National Institutes of Health, 10 Center Drive, 4S-235 (MSC 1379), Bethesda, MD 20892-I379, USA, Tel: + I 30 I 402 7956, Fax: + | 30 I 480 7795, E-mail: weinberd@intra.nimh.nih.gov

${ }^{2}$ Current address: Department of Psychiatry, University of Hamburg, Martinistr. 52, 20246 Hamburg, Germany.

${ }^{3}$ Current address: Stanley Foundation Research Programs, 5430 Grosvenor Lane, Suite 200 Bethesda, MD 208I4, USA.

Received 20 February 2002; revised 15 April 2003; accepted 16 April 2003

Online publication: 28 April 2003 at http://www.acnp.org/citations/ Npp042802079/default.pdf
In vitro, clozapine has a high affinity for a large variety of neurotransmitter receptors, including $5 \mathrm{HT}_{2 \mathrm{~A}}, 5 \mathrm{HT}_{2 \mathrm{C}}, 5 \mathrm{HT}_{6}$, $5 \mathrm{HT}_{7}, \mathrm{D}_{4}, \alpha_{1}$ and all five subtypes of muscarinic receptors, but has only moderate affinity at dopamine $\mathrm{D}_{1}$ and $\mathrm{D}_{2}$ receptors (Bolden et al, 1992; Bymaster et al, 1996; Schotte et al, 1996). In vivo PET and SPECT studies of the receptor occupancy of clozapine have shown that clozapine combines moderate $\mathrm{D}_{2}$ receptor occupancy with high $5 \mathrm{HT}_{2}$ receptor occupancy (Farde et al, 1992; Kapur et al, 1999). So far, no imaging studies of muscarinic receptors have been performed in subjects treated with clozapine.

Cholinergic projections are ubiquitous in the brain and may be involved in the modulation of several processes thought to be dysfunctional in schizophrenia, such as memory (Goldberg et al, 1993), sleep (Jus et al, 1973), eye movements (Holzman et al, 1973), and motor control (Manschreck, 1986). Striatal cholinergic interneurons may also be involved in the pathophysiology and treatment of motor disturbances in schizophrenia. In addition to their beneficial effect on motor side effects of antipsychotics, anticholinergic medications have been associated with worsening of positive symptoms and improvement of negative symptoms in schizophrenia (Tandon et al, 1991). Neuropathologic studies reveal a reduction of muscarinic 
receptors in schizophrenia (Dean et al, 1996; Crook et al, 1999, 2000, 2001).

Quinuclidinyl benzilate (QNB) has been used for years as an in vitro marker of muscarinic receptors and has subnanomolar affinity at all five muscarinic receptor subtypes (Bolden et al, 1992). [I-123]IQNB, the iodinated form of QNB, has been used in SPECT studies for in vivo measurements of muscarinic receptor availability (Eckelman et al, 1984; Weinberger et al, 1991; Sunderland et al, 1995). Using [I-123]IQNB SPECT, our group has previously reported reduced muscarinic receptor availability in unmedicated schizophrenic patients in vivo (Raedler et al, 2003), a finding similar to that of the post-mortem studies. We also have shown that treatment with the atypical antipsychotic olanzapine results in dose-dependent moderate muscarinic occupancy in the cortex and the basal ganglia and high muscarinic occupancy in the thalamus and the pons (Raedler et al, 2000).

While most research concerning the unique properties of clozapine has focused on antagonism at serotonin and dopamine receptors, it is possible that some of the beneficial and deleterious effects of clozapine can be explained by its actions on muscarinic receptors. Based on our experience in previous [I-123]IQNB SPECT studies as well as the in vitro binding of clozapine to muscarinic receptors, we predicted that the effects of clozapine on muscarinic receptor availability could be measured in vivo by this noninvasive technique.

\section{METHODS}

\section{Subjects}

We studied eight in-patients at the National Institute of Mental Health Neuropsychiatric Research Hospital at St Elizabeths in Washington, DC. All subjects gave written informed consent to participate in the [I-123]IQNB SPECT protocol, as approved by the NIMH Institutional Review Board. All subjects received a medical, neurological and psychiatric evaluation prior to enrollment. This included a brain MRI to rule out structural disease and for coregistration with SPECT images. The subjects were free of comorbid disorders, including substance abuse during the 6 months preceding this study. All subjects were chronically ill and were diagnosed with schizophrenia $(n=6)$ or schizoaffective disorder $(n=2)$ (DSM IV, American Psychiatric Association, 1994). All subjects had received other antipsychotics and supplemental anticholinergic treatment (benztropine $=6$; trihexyphenidyl =2) before treatment with clozapine. Prior to clozapine treatment initiation, other medications with known antimuscarinic properties were tapered and discontinued over a 2-week period. Other medication dosages were held constant for at least 2 weeks prior to SPECT scanning.

In order to study the effects of low doses of clozapine on muscarinic receptors, four subjects underwent [I-123]IQNB SPECT scans during the initiation of clozapine treatment. These subjects received treatment with daily doses of 50, 75 (two patients), or $150 \mathrm{mg}$ for 3 days prior to SPECT scanning. Subsequently, clozapine dosage was optimized according to the clinical impression of the research ward team. Optimal clozapine dosage (range 200-450 mg/day) was held constant for 2 weeks prior to [I-123]IQNB SPECT. Four subjects were studied on two doses of clozapine. Of the eight subjects, seven were studied on clinically optimal clozapine doses. The [I-123]IQNB SPECT scan on the higher clozapine dose was used for the group analysis of muscarinic receptor availability. Table 1 summarizes the demographic data.

On the day of the [I-123]IQNB SPECT scan, the patients were rated with the Positive and Negative Symptom Assessment Scale (PANSS, Kay et al, 1986), Modified Abnormal Involuntary Movement Scale (AIMS, Wyatt, 1993) and the Wechsler Visual Memory Scale (WVMS, Wechsler, 1987). In 10 subjects, the National Psychopharmacology Laboratory (Knoxville, Tennessee) assessed clozapine blood levels on the day of SPECT scan with estimated coefficient of variation less than $\pm 10 \%$ (Pickar et al, 1996).

Contemporaneously, 12 unmedicated schizophrenia patients were scanned identically as the comparison group. Prior medication histories of comparison subjects were similar to those of treatment subjects: seven had received typical antipsychotics and four had been treated with

Table I Subject Demographics

\begin{tabular}{|c|c|c|c|c|c|c|c|c|}
\hline Subject & $\begin{array}{c}\text { Age } \\
\text { (years) }\end{array}$ & Sex & Diagnosis $^{\mathbf{a}}$ & $\begin{array}{l}\text { Illness } \\
\text { duration } \\
\text { (years) }\end{array}$ & $\begin{array}{l}\text { Anticholinergic } \\
\text { medication prior } \\
\text { to this study }\end{array}$ & $\begin{array}{l}\text { Concomitant } \\
\text { medication }\end{array}$ & $\begin{array}{l}\text { Clozapine dose } \\
\text { (mg/day) }\end{array}$ & $\begin{array}{c}\text { Clozapine } \\
\text { blood level } \\
\text { (ng/ml) }\end{array}$ \\
\hline । & 34 & $M$ & SA & 14 & Benztropine & None & 225 & 246 \\
\hline \multirow[t]{2}{*}{2} & 44 & $M$ & SA & 21 & Benztropine & Valproic acid & 50 & 40 \\
\hline & & & & & & Lithium & 200 & 193 \\
\hline \multirow[t]{2}{*}{3} & 37 & $M$ & CUS & 19 & Benztropine & None & 250 & 110 \\
\hline & & & & & & & 300 & 150 \\
\hline 4 & 32 & $\mathrm{~F}$ & CPS & 9 & Trihexyphenidyl & None & 75 & 77 \\
\hline \multirow[t]{2}{*}{5} & 46 & $M$ & CPS & 21 & Benztropine & Ranitidine & 75 & 133 \\
\hline & & & & & & & 200 & 396 \\
\hline \multirow[t]{2}{*}{6} & 25 & $M$ & CUS & 4 & Trihexyphenidyl & Propranolol & 150 & NA \\
\hline & & & & & & & 450 & 215 \\
\hline 7 & 38 & $M$ & CPS & & Benztropine & Ranitidine & 250 & NA \\
\hline 8 & 48 & $M$ & CPS & 21 & Benztropine & None & 300 & 207 \\
\hline
\end{tabular}

aSA = Schizoaffective disorder; CUS = chronic undifferentiated schizophrenia; CPS = chronic paranoid schizophrenia.

Clinically optimal doses of clozapine in each patient, which were used in determining muscarinic acetylcholine receptor occupancy from the [I- I 23]IQNB SPECT data, are shown in bold. 
atypical antipsychotics; five subjects had also received adjunctive treatment with anticholinergic medication (benztropine). At the time of their [I-123]IQNB scans, comparison subjects had been unmedicated for a median 17 days (range 7-180 days) (Raedler et al, 2003). The average age of the comparison group (34.6 \pm 6.8 years, range: $24-44$ years) did not differ significantly $(t=1.20, \mathrm{df}=22, p=0.24)$ from the treatment group (38.2 \pm 7.8 years, range: $25-48$ years). Similarly, the gender ratio of the comparison group $(8 \mathrm{M}: 4 \mathrm{~F})$ did not differ significantly $\left(\chi^{2}=2.27, \mathrm{df}=1\right.$, $p=0.13)$ from the treatment group $(8 \mathrm{M}: 1 \mathrm{~F})$.

\section{SPECT Procedure}

$(R, S)$-[I-123]IQNB synthesis followed previously described procedures (Lee et al, 1996). Each subject received an intravenous injection of about $7 \mathrm{mCi}$ of [I-123]IQNB (mean: $6.9 \pm 1.6 \mathrm{mCi}$, range: $4.9-10.0 \mathrm{mCi}$ ) at $13.00 \mathrm{~h}$. The subjects received five drops of Lugol's solution on the day prior to injection and for 3 subsequent days to reduce radiation exposure to the thyroid. The average injected dose for comparison subjects $(6.5 \pm 1.5 \mathrm{mCi})$ did not differ significantly $(t=1.23 ; \mathrm{df}=22 ; p=0.23)$ from the treatment group $(7.3 \pm 1.7 \mathrm{mCi})$. A 60 -min SPECT scan was performed $21 \mathrm{~h}$ after injection when nonspecific binding in the cerebellum was indistinguishable from the scanner background count rate. For the scan, the subjects reclined into the CERASPECT (Digital Scintigraphics, Waltham, MA) dedicated brain SPECT camera. A laser beam was used to align the canthomeatal line to the transverse plane of the camera. The SPECT camera was calibrated for each scan session by imaging a 1-1 uniform flood phantom of known radioactivity.

[I-123]IQNB scans were acquired in a step-and-shoot mode over 120 projections with a high-resolution collimator ( $7.5 \mathrm{~mm}$ full width at half maximum) A photopeak window (143-175 keV) and windows for scatter and septal penetration correction (175-191, 127-143 keV) were recorded. SPECT data were reconstructed with a Butterworth filter (cutoff $=1 \mathrm{~cm}$, power factor $=10$ ) as a 64 slice $\times 128 \times 128$ volume of isotropic $1.67-\mathrm{mm}$ voxels.

\section{Image Analysis}

The image analysis has been previously described in detail (Raedler et al, 2000; Raedler et al, 2003). An MRI was obtained on each subject with a $1.5 \mathrm{~T}$ Signa (General Electric Medical Systems, Milwaukee, WI) scanner, using a spoiled GRASS sequence $(\mathrm{TR}=24 \mathrm{~ms}, \mathrm{TE}=5 \mathrm{mse}$ that generated 124 contiguous sagittal slices (thickness: $1.5 \mathrm{~mm}$, field of view: $240 \mathrm{~mm}$, matrix: $256 \times 256$ matrix). Using the public domain NIH Image software, the MRI volume was rotated so that a line connecting the anterior and posterior commissures in a midsagittal slice was horizontal. The MRI was then scaled to the dimensions of the SPECT scans and imported to the CERASPECT console. Based on gross anatomical features, regions of interest (ROIs) were drawn on central slices of the SPECT scan in three orthogonal planes. These ROIs were then superimposed onto the MRI and aligned for optimal fit to the MRI. Subsequently, these reoriented ROIs were transferred back to the SPECT scan and the SPECT scans rotated and translated to fit into the alignment ROIs. If necessary, this process was repeated to assure optimal coregistration. Using standard atlases (Aquilonius and Eckernas, 1980; Talairach and Tournoux, 1988; Duvernoy, 1991), anatomical ROIs for the cerebellum, pons, thalamus, caudate, and putamen as well as medial frontal, lateral frontal, temporal, parietal, and occipital cortex were drawn on five contiguous slices of the MRI scan to form a volume of interest (VOI) for each area. These ROIs were then transferred onto the coregistered SPECT scans. Data from right- and left-sided structures were averaged together. The average concentration of activity in each VOI was determined by dividing the counts per minute by the volume of the VOI; these data were decay corrected and converted to $\mathrm{nCi} / \mathrm{ml}$ tissue using data from the calibration phantom. Finally, data were normalized to the injected dose to yield units of $\mathrm{nCi} / \mathrm{ml}$ tissue per $\mathrm{mCi}$ injected dose, and cerebellum data, assumed to estimate nonspecific binding, were subtracted from each VOI value. These values serve as our measure of muscarinic receptor availability and to evaluate the percent reduction when comparing groups.

\section{Statistical Analyses}

Statistics were evaluated using Statistica for Windows 5.1. (StatSoft, Inc., Tulsa, OK) and Microsoft Excel (Microsoft Corp., Redmond, WA). Multivariate Hotelling's $T^{2}$ and post hoc Student's $t$-tests (independent samples) compared treatment subjects with unmedicated subjects. Dichotomous variables were analyzed with $\chi^{2}$ tests. Correlations were assessed with Spearman's rank order correlation coefficient $(R)$. In a pilot analysis employing nonlinear curve fitting with Solver in Excel, we estimated the in vivo muscarinic availability $v s$ clozapine dose curve assuming clozapine binding to be in equilibrium with receptors after 2 weeks of fixed dosing.

\section{RESULTS}

Figure 1 shows an illustrative scan of a subject at a daily clozapine dose of $150 \mathrm{mg}$ (top row) and $450 \mathrm{mg}$ (middle row). Treatment subjects and comparison subjects showed similar patterns of [I-123]IQNB binding with highest muscarinic receptor availability in the cortex and the basal ganglia and lower availability in the thalamus and the pons.

Overall, we found lower muscarinic receptor availability (Table 2) in patients treated with clozapine than in unmedicated schizophrenics: the seven subjects treated with at least $200 \mathrm{mg} /$ day of clozapine (mean $275 \pm 88 \mathrm{mg}$ / day) exhibited significantly lower [I-123]IQNB binding (multivariate Hotelling's $T^{2}=107.8 ; \quad \mathrm{F}(8,10)=7.92$; $p<0.002)$. These differences reached significance for every VOI (all $t>2.96$; all $p<0.008$ ) in post hoc $t$-tests. Table 3 summarizes the percent reduction in muscarinic receptor availability in detail. The reductions ranged between 41 and $49 \%$ in the striatum ( $45 \%$ combined) and 57 and $59 \%$ in the cortex (58\% combined) to higher reductions in the pons (66\%) and the thalamus (79\%).

Negative correlations between daily clozapine dose and muscarinic availability were significant in all ROIs (all Spearman $R<-0.7$, all $p<0.02)$ except pons $(R=-0.36$, $p=0.24)$. The strongest negative correlation between daily 


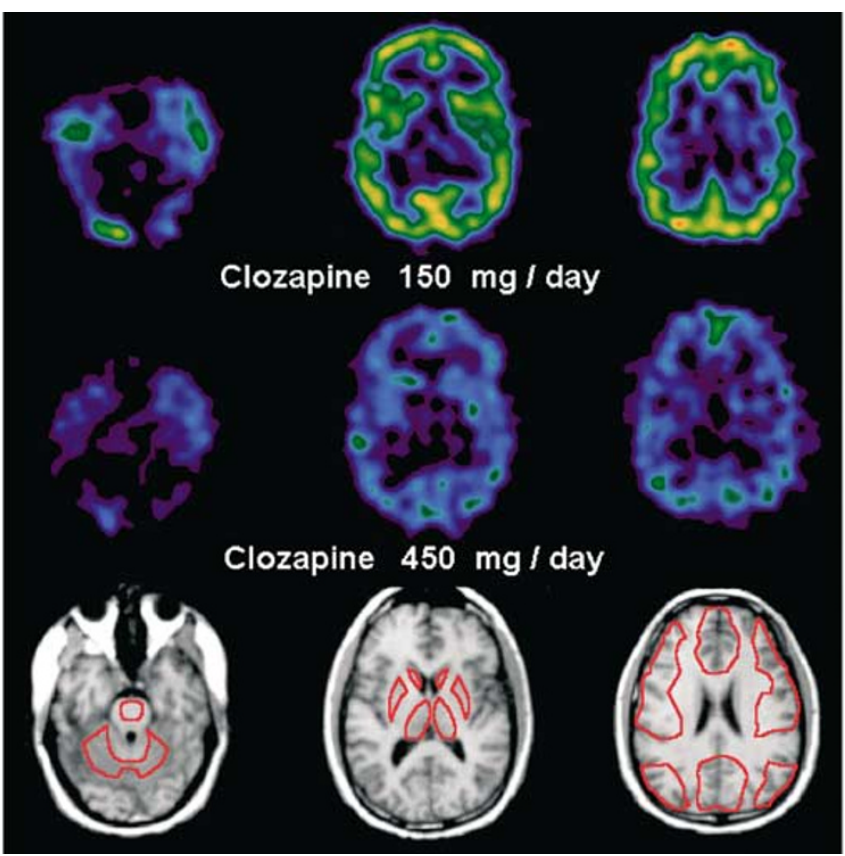

Figure I Illustrative [I- I23]|QNB SPECT images of a subject scanned at both $150 \mathrm{mg} /$ day of clozapine (top row) and $450 \mathrm{mg} /$ day of clozapine (middle row). The leftmost slices are at the level of the pons and pass through the posterior poles of the occipital lobes, the slices in the center column are through the middle of the thalamus, and the rightmost slices are through the dorsal arch of the corpus callosum. The bottom row shows the corresponding slices of the coregistered MRI and the ROls for these slices.

clozapine dose and muscarinic availability was in the putamen $(R=-0.82, \quad p<0.001)$. Negative correlations between clozapine serum levels and muscarinic receptor availability were significant in the lateral and the medial frontal cortex $(R=-0.74, p<0.02$ and $R=-0.65, p<0.05$, respectively). There were no significant correlations with symptom severity on the different psychopathology scales (PANSS), with extrapyramidal motor scales (AIMS) or with the WVMS.

The nonlinear curve fit analysis of muscarinic availability data predicts that maximal clinical doses of clozapine $(900 \mathrm{mg} /$ day) may reduce availability by roughly $70 \%$ in the striatum, $80 \%$ in the cortex, $90 \%$ in the thalamus, and $70 \%$ in the pons (Figure 2).

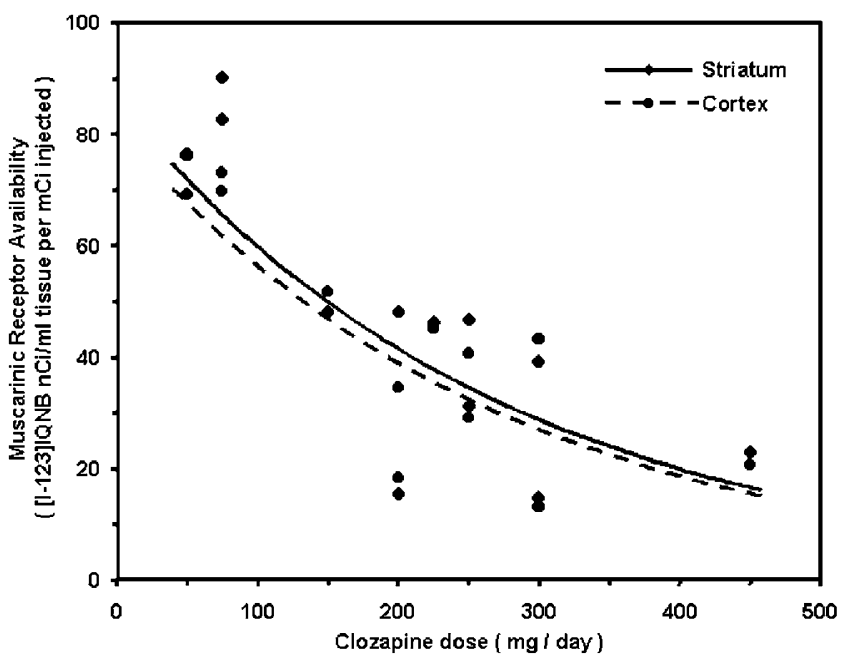

Figure 2 Relation between daily dose of clozapine $(\mathrm{mg} /$ day) and muscarinic receptor availability, as measured by [I- I23]IQNB binding ( $\mathrm{nCi}$ ) $\mathrm{ml}$ tissue per $\mathrm{mCi}$ injected), in the striatum (average of caudate and putamen VOIs) and the cortex (average of medial frontal, lateral frontal, temporal, and occipital cortex VOls).

Table 3 Mean Muscarinic Acetylcholine Receptor Availability Reduction in Patients Treated with at least $200 \mathrm{mg} /$ day of Clozapine ( $n=7$; Mean Dose $275.0 \pm 87.8 \mathrm{mg} /$ day; Range 200 $450 \mathrm{mg} /$ day $)$ Relative to Unmedicated Patients $(n=12)$

\begin{tabular}{lc}
\hline vol & $\begin{array}{c}\text { Percent reduction } \\
\text { of muscarinic } \\
\text { receptor availability (\%) }\end{array}$ \\
\hline Caudate & 41.3 \\
Putamen & 48.6 \\
Basal ganglia $^{a}$ & 45.3 \\
Thalamus & 78.9 \\
Pons & 65.5 \\
Medial frontal cortex & 56.8 \\
Lateral frontal cortex & 59.4 \\
Temporal cortex & 56.8 \\
Occipital cortex & 58.0 \\
Cortex & 57.7 \\
\hline
\end{tabular}

aMean of caudate and putamen VOls.

bMean of all cortical VOls.

Table 2 Muscarinic Receptor Availability (Mean \pm SD) in Schizophrenia Patients Treated with Clozapine at least $200 \mathrm{mg} /$ day (Mean Dose $275.0 \pm 87.8 \mathrm{mg} /$ day) Compared to Unmedicated Schizophrenia Patients (Multivariate Hotelling's $T^{2}=107.84 ; F(8,10)=7.92 ; p<0.002$ )

\begin{tabular}{|c|c|c|c|c|}
\hline \multirow[b]{2}{*}{ vol } & \multicolumn{2}{|c|}{ [I-I 23]IQNB binding ( $\mathrm{nCi} / \mathrm{ml}$ tissue per $\mathrm{mCi}$ injected) } & \multirow[b]{2}{*}{$t-$ Value $(d f=I 7)$} & \multirow[b]{2}{*}{$p$-Value } \\
\hline & Clozapine $(n=7)$ & Unmedicated $(n=12)$ & & \\
\hline Caudate & $31.0 \pm 12.1$ & $52.8 \pm 17.0$ & 2.96 & 0.008 \\
\hline Putamen & $33.7 \pm 13.7$ & $65.6 \pm 21.4$ & 3.52 & 0.003 \\
\hline Thalamus & $6.5 \pm 3.0$ & $30.6 \pm 10.0$ & 6.16 & 0.0001 \\
\hline Pons & $4.5 \pm 3.4$ & $12.9 \pm 6.9$ & 3.01 & 0.007 \\
\hline Medial frontal cortex & $27.9 \pm 11.1$ & $64.8 \pm 15.0$ & 5.62 & 0.0001 \\
\hline Lateral frontal cortex & $27.3 \pm 11.2$ & $67.2 \pm 14.7$ & 6.20 & 0.0001 \\
\hline Temporal cortex & $34.3 \pm 12.4$ & $79.5 \pm 16.9$ & 6.13 & 0.0001 \\
\hline Occipital cortex & $31.7 \pm 12.7$ & $75.5 \pm 15.5$ & 6.32 & 0.0001 \\
\hline
\end{tabular}




\section{DISCUSSION}

This pilot study is the first to measure the reduction of central muscarinic receptor availability in schizophrenia patients treated with clozapine. Relative to a matched sample of unmedicated patients, we found significant reductions of $45 \%$ (striatum) to $79 \%$ (thalamus) of muscarinic availability in patients treated with 200$450 \mathrm{mg} /$ day of clozapine. In both samples, the pattern of [I-123]IQNB binding, our measure of muscarinic availability, was similar to that described in earlier reports (Weinberger et al, 1991; Sunderland et al, 1995; Raedler et al, 2000). In a related [I-123]IQNB SPECT study, we found a significant reduction of muscarinic availability in unmedicated schizophrenia patients (Raedler et al, 2003), a finding consistent with several neuropathological studies of muscarinic receptors in schizophrenia subjects (Dean et al, 1996; Crook et al, 1999, 2000, 2001). Thus, we used unmedicated schizophrenia patients as a comparison group because comparison to normal controls might inappropriately overestimate the reduction of muscarinic availability as a result of clozapine treatment.

The reduction of muscarinic receptor availability by clozapine implies a potency that differs from its in vivo potency at dopamine $\mathrm{D}_{2}$ and serotonin $5 \mathrm{HT}_{2}$ receptors as measured in PET and SPECT studies. While clinical doses of most antipsychotics result in $\mathrm{D}_{2}$ receptor occupancy by $70 \%$ (estimated by IBZM SPECT or raclopride PET), the reduction of $\mathrm{D}_{2}$ receptor availability does not exceed $65 \%$ for clinical doses of clozapine (Farde et al, 1992; Nordstrom et al, 1993b; Kapur et al, 1999), and $5 \mathrm{HT}_{2}$ receptors are almost completely occupied by low doses of clozapine (Nordstrom et al, 1993a, 1995; Travis et al, 1998). Our data indicate that treatment with clozapine reduces muscarinic receptor availability in the striatum and the cortex by an amount similar to the occupancy of striatal $\mathrm{D}_{2}$ receptors, while it is substantially lower than the occupancy of $5 \mathrm{HT}_{2}$ receptors.

The relation between muscarinic receptor occupancy and beneficial or deleterious effects is poorly understood. In studies of the dopaminergic system, a threshold of $60 \%$ dopamine $\mathrm{D}_{2}$ receptor occupancy has been suggested for antipsychotic efficacy, while a threshold of about $75-80 \%$ was postulated for the emergence of motor side effects (Nordstrom et al, 1993b). Similar thresholds have not been established for the effects of anticholinergic medications on the muscarinic system and the relation between muscarinic receptor occupancy and anticholinergic side effects remains unknown. In clinical practice, treatment with clozapine frequently results in some anticholinergic side effects such as constipation, urinary retention, impaired accommodation, and tachycardia. A quantitative assessment of such side effects was not undertaken in this study and all patients tolerated clozapine well, although minor expected side effects were noted.

Little is known about the direct effects of clozapine on muscarinic receptors in humans. In rodent studies, chronic treatment with clozapine resulted in increased muscarinic receptor densities in the cortex, the striatum, and the hippocampus (Friedman et al, 1983; Boyson et al, 1988). Similarly, little is known about the possible effects of muscarinic receptor antagonism on other neurotransmitter systems. In PET studies, Dewey et al $(1990,1993)$ have shown that muscarinic antagonists may increase striatal synaptic dopamine.

It has been thought that clozapine acts as a pure antagonist at the muscarinic receptor. However, this concept has been challenged by clinical observations that higher doses of clozapine frequently result in hypersalivation that can be effectively treated with anticholinergics such as pirenzepine. More recent studies suggest that clozapine may act in a dose-dependent manner as a partial agonist at different muscarinic receptor subtypes (Zorn et al, 1994; Zeng et al, 1997; Olianas et al, 1999, Michal et al, 1999). In this context, it is important to point out that [I123]IQNB SPECT assesses muscarinic receptor availability only, but not the function of clozapine at these receptors vis-à-vis agonist or antagonist.

We emphasize the preliminary nature of our findings. This study was carried out in a small sample of subjects, who were treated with low to moderate doses of clozapine. Consistently, the serum levels of clozapine were relatively low. We neither used a fixed dose regimen nor did we employ a within-subject design in which patients were scanned before and after treatment; medicated patients were instead compared to a separate cohort of unmedicated patients. SPECT studies were performed at least 5 weeks after the initiation of washout of other antipsychotic and antimuscarinic medications. We feel that this washout interval is sufficient to insure that the muscarinic receptor availability is not confounded by residual effects of previous medications. This concept is supported by the results from our previous study, where there was no significant correlation between duration of the unmedicated interval and muscarinic receptor availability (Raedler $e t a l$, 2003).

It is conceivable that medication-induced changes in brain function and subsequent influences on brain physiology, blood flow, or endogenous acetylcholine levels may affect IQNB uptake differently between the treatment group and the unmedicated comparison group. However, it seems unlikely that these effects would reduce IQNB uptake to the extent that we have observed and we ascribe our observations primarily to direct blockade by clozapine. Despite these limitations, we were able to measure the in vivo occupancy of muscarinic receptors in patients treated with clozapine. Further evidence for the in vivo effects of clozapine on the muscarinic receptor should be gained from additional studies using higher doses of clozapine.

\section{ACKNOWLEDGEMENTS}

We thank the patients who volunteered for this study. We also thank Julia G Gorey, CNMT, and Kan S Lee, PhD, for their assistance in conducting the SPECT scans.

\section{REFERENCES}

American Psychiatric Association (1994). Diagnostic and Statistical Manual of Mental Disorders, 4th edn American Psychiatric Association Press: Washington, DC. 
Aquilonius SM, Eckernas SA (1980). A Colour Atlas of the Human Brain. Raven Press: New York.

Bolden C, Cusack B, Richelson E (1992). Antagonism by antimuscarinic and neuroleptic compounds at five cloned human muscarinic cholinergic receptors expressed in Chinese hamster ovary cells. J Pharm Exp Ther 260: 576-580.

Boyson SJ, McGonigle P, Luthin GR, Wolfe BB, Molinoff PB (1988). Effects of chronic administration of neuroleptic and anticholinergic agents on densities of $\mathrm{D}_{2}$ dopamine and muscarinic cholinergic receptors in rat striatum. J Pharmacol Exp Ther 244: 987-993.

Bymaster FP, Calligaro DO, Falcone JF, Marsh RD, Moore NA, Tye NC et al (1996). Radioreceptor binding profile of the atypical antipsychotic olanzapine. Neuropsychopharmacology 14: 87-96.

Crook JM, Dean B, Pavey G, Copolov D (1999). The binding of $\left[{ }^{3} \mathrm{H}\right]$ AF-DX 384 is reduced in the caudate-putamen of subjects with schizophrenia. Life Sci 64: 1761-1771.

Crook JM, Tomaskovic-Crook E, Copolov DL, Dean B (2000). Decreased muscarinic receptor binding in subjects with schizophrenia: a study of the human hippocampal formation. Biol Psychiatry 48: 381-388.

Crook JM, Tomaskovic-Crook E, Copolov DL, Dean B (2001). Low muscarinic receptor binding in prefrontal cortex from subjects with schizophrenia: a study of Brodmann's areas $8,9,10$, and 46 and the effects of neuroleptic drug treatment. Am J Psychiatry 158: 918-925.

Dean B, Crook JM, Opeskin K, Hill C, Keks N, Copolov DL (1996). The density of muscarinic $M_{1}$ receptors is decreased in the caudate-putamen of subjects with schizophrenia. Mol Psychiatry 1: $54-58$.

Dewey SL, Brodie JD, Fowler JS, MacGregor RR, Schlyer DK, King PT et al (1990). Positron emission tomography studies of dopaminergic/cholinergic interactions in the baboon brain. Synapse 6: 321-327.

Dewey SL, Smith GS, Logan J, Brodie JD, Simkowitz P, MacGregor $\mathrm{RR}$ et al (1993). Effects of central cholinergic blockade on striatal dopamine release measured with positron emission tomography in normal subjects. Proc Nat Acad Sci USA 90: 11816-11820.

Duvernoy HM (1991). The Human Brain. Surface, Three-Dimensional Sectional Anatomy and MRI. Springer-Verlag: Vienna.

Eckelman WC, Reba RC, Rzeszotarski WJ (1984). External imaging of cerebral muscarinic acetylcholine receptors. Science 223: 291-292.

Farde L, Nordstrom AL, Wiesel FA, Pauli S, Halldin C, Sedvall G (1992). Positron emission tomographic analysis of central $D_{1}$ and $\mathrm{D}_{2}$ dopamine receptor occupancy in patients treated with classical neuroleptics and clozapine - relation to extrapyramidal side effects. Arch Gen Psychiatry 49: 538-544.

Friedman E, Gianutsos G, Kuster J (1983). Chronic fluphenazine and clozapine elicit opposite changes in brain muscarinic receptor binding: implications for understanding tardive dyskinesia. J Pharmacol Exp Ther 226: 7-12.

Goldberg TE, Gold JM, Greenberg R, Griffin S, Schulz SC, Pickar D et al (1993). Contrasts between patients with affective disorders and patients with schizophrenia on a neuropsychological test battery. Am J Psychiatry 150: 1355-1362.

Holzman PS, Proctor LR, Hughes DW (1973). Eye tracking patterns in schizophrenia. Science 181: 179-181.

Jus K, Bouchard M, Jus A, Villeneuve A, Lachance R (1973). Sleep EEG studies in untreated long-term schizophrenic patients. Arch Gen Psychiatry 29: 386-290.

Kane JM, Honigfeld G, Singer J, Meltzer HY (1988). Clozapine for the treatment-resistant schizophrenic: a double-blind comparison with chlorpromazine. Arch Gen Psychiatry 45: 789-796.

Kapur S, Zipursky RB, Remington G (1999). Clinical and theoretical implications of $5-\mathrm{HT}_{2}$ and $\mathrm{D}_{2}$ receptor occupancy of clozapine, risperidone, and olanzapine in schizophrenia. $A m$ J Psychiatry 156: 286-293.

Kay SR, Opler LA, Fiszbein A (1986). Positive and Negative Syndrome Scale (PANSS). Multi-Health Systems: North Tonawanda, NY.

Lee KS, He XS, Jones DW, Coppola R, Gorey JG, Knable MB et al (1996). An improved method for rapid and efficient radioiodination of iodine-123-IQNB. J Nucl Med 37: 2021-2024.

Manschreck TC (1986). Motor abnormalities in schizophrenia. In: Nasrallah HA, Weinberger DR (eds) Handbook of Schizophrenia. Elsevier: Amsterdam. pp 65-96.

Michal P, Lysikova M, El-Fakahany EE, Tucek S (1999). Clozapine interaction with the $\mathrm{M}_{2}$ and $\mathrm{M}_{4}$ subtypes of muscarinic receptors. Eur J Pharmacol 376: 119-125.

Nordstrom AL, Farde L, Halldin C (1993a). High 5- $\mathrm{HT}_{2}$ receptor occupancy in clozapine treated patients demonstrated by PET. Psychopharmacology (Berl) 110: 365-367.

Nordstrom AL, Farde L, Nyberg S, Karlsson P, Halldin C, Sedvall G (1995). $\mathrm{D}_{1}, \mathrm{D}_{2}$, and $5-\mathrm{HT}_{2}$ receptor occupancy in relation to clozapine serum concentration: a PET study of schizophrenic patients. Am J Psychiatry 152: 1444-1449.

Nordstrom AL, Farde L, Wiesel FA, Forslund K, Pauli S, Halldin C et al (1993b). Central D2-dopamine receptor occupancy in relation to antipsychotic drug effects: a double-blind PET study of schizophrenic patients. Biol Psychiatry 33: 227-235.

Olianas MC, Maullu C, Onali P (1999). Mixed agonist-antagonist properties of clozapine at different human cloned muscarinic receptor subtypes expressed in Chinese hamster ovary cells. Neuropsychopharmacology 20: 263-270.

Pickar D, Su T-P, Weinberger DR, Coppola R, Malhotra AK, Knable $\mathrm{MB}$ et al (1996). Individual variation in $\mathrm{D}_{2}$ dopamine receptor occupancy in clozapine-treated patients. Am J Psychiatry 153: 1571-1578.

Raedler TJ, Knable MB, Jones DW, Lafargue T, Urbina RA, Egan $\mathrm{MF}$ et al (2000). In vivo olanzapine occupancy of muscarinic acetylcholine receptors in patients with schizophrenia. Neuropsychopharmacology 23: 56-68.

Raedler TJ, Knable MB, Jones DW, Urbina RA, Gorey J, Lee KS et al (2003). In vivo determination of muscarinic acetylcholine receptor availability in schizophrenia. Am J Psychiatry 160: 118-127.

Rosenheck R, Cramer J, Xu W, Thomas J, Henderson W, Frisman L et al (1997). A comparison of clozapine and haloperidol in hospitalized patients with refractory schizophrenia. New Engl J Med 337: 809-815.

Schotte A, Janssen PF, Gommeren W, Luyten WH, Van Gompel P, Lesage AS et al (1996). Risperidone compared with new and reference antipsychotic drugs: in vitro and in vivo receptor binding. Psychopharmacology (Berl) 124: 57-73.

Sunderland T, Esposito G, Molchan SE, Coppola R, Jones DW, Gorey J et al (1995). Differential cholinergic regulation in Alzheimer's patients compared to controls following chronic blockade with scopolamine: a SPECT study. Psychopharmacology (Berl) 121: 231-241.

Talairach J, Tournoux P (1988). Co-Planar Stereotaxic Atlas of the Human Brain. Thieme Medical Publishers: New York.

Tandon R, Shipley JE, Greden JF, Mann NA, Eisner WH, Goodson J (1991). Muscarinic cholinergic hyperactivity in schizophrenia. Relationship to positive and negative symptoms. Schizophr Res 4: 23-30.

Travis MJ, Busatto GF, Pilowsky LS, Mulligan R, Acton PD, Gacinovic $S$ et al (1998). 5- $\mathrm{HT}_{2 \mathrm{~A}}$ receptor blockade in patients with schizophrenia treated with risperidone or clozapine. A SPET study using the novel 5- $\mathrm{HT}_{2 \mathrm{~A}}$ ligand [I-123]5-I-R-91150. $\mathrm{Br}$ J Psychiatry 173: 236-241.

Wechsler D (1987). Wechsler Memory Scale-Revised Manual. Psychological Corporation: New York. 
Weinberger DR, Gibson R, Coppola R, Jones DW, Molchan S, Sunderland $\mathrm{T}$ et al (1991). The distribution of cerebral muscarinic acetylcholine receptors in vivo in patients with dementia. A controlled study with ${ }^{123} \mathrm{IQNB}$ and single photon emission computed tomography. Arch Neurol 48: $169-176$.

Wyatt R (1993). Practical Psychiatric Practice: Clinical Interview Forms, Rating Scales, and Practice Handouts. American Psychiatric Press: Washington, DC.
Yeomans JS (1995). Role of tegmental cholinergic neurons in dopaminergic activation, antimuscarinic psychosis and schizophrenia. Neuropsychopharmacology 12: 3-16.

Zeng XP, Le F, Richelson E (1997). Muscarinic $\mathrm{m}_{4}$ receptor activation by some atypical antipsychotic drugs. Eur J Pharmacol 321: 349-354.

Zorn SH, Jones SB, Ward KM, Liston DR (1994). Clozapine is a potent and selective muscarinic $\mathrm{M}_{4}$ receptor agonist. Eur $J$ Pharmacol 269: R1-R2. 